\title{
PENGARUH PENDEKATAN SAINTIFIK TERHADAP MOTIVASI DAN HASIL BELAJAR BIOLOGI SISWA
}

\author{
Diah Dwi Mayasari $^{1}$, Yunita Wardianti ${ }^{2}$, Yuli Febrianti ${ }^{3}$ \\ STKIP PGRI Lubuklinggau ${ }^{1,2,3}$ \\ diahdwimayas@gmail.com ${ }^{1}$
}

\begin{abstract}
ABSTRAK
Tujuan penelitian ini adalah untuk mengetahui pengaruh pendekatan saintifik terhadap motivasi dan hasil belajar siswa biologi kelas X SMA Negeri 6 Model Lubuklinggau. Metode penelitian yang digunakan adalah penelitian kuantitatif dengan jenis penelitian eksperimen murni menggunakan desain pre-test and posttest group design. Populasi dalam penelitian ini adalah seluruh siswa kelas $\mathrm{X}$ MIPA yang berjumlah 88 siswa. Sampel diambil secara acak sehingga didapatkan kelas X MIPA 1 berjumlah 30 siswa sebagai kelas eksperimen dan kelas X MIPA 2 berjumlah 27 siswa sebagai kelas kontrol, pengumpulan data dilakukan dengan teknik tes dan angket. Hasil penelitian, diketahui nilai $t_{\text {hitung }}$ untuk motivasi didapatkan hasil 6,631 $>\mathrm{t}_{\text {tabel }}=1,671$, dengan taraf signifikan $\alpha=0.05$ dan $\mathrm{dk} 55$. Data yang dikumpulkan untuk analisis hasil belajar dengan taraf signifikan $\alpha=$ $0.05 \mathrm{dan} \mathrm{dk} 55$, diketahui nilai $\mathrm{t}_{\text {hitung }}=11,23>\mathrm{t}_{\text {tabel }}=1,671$. Ada perbedaan skor motivasi dan hasil belajar siswa secara signifikan sebelum dan sesudah diberikan intervensi belajar menggunakan pendekatan saintifik. Simpulan, pendekatan saintifik dalam pembelajaran biologi memiliki pengaruh yang signifikan terhadap motivasi dan hasil belajar siswa
\end{abstract}

Kata Kunci : hasil belajar, motivasi, pendekatan saintifik.

\section{ABSTRACT}

The purpose of this study was to determine the effect of the scientific approach to the motivation and learning outcomes of biology class X students of SMA Negeri 6 Model Lubuklinggau. The research method used is quantitative research with pure experimental research using pre-test and post-test group design. The population in this study were all students of class X MIPA, amounting to 88 students. Samples were taken randomly so that there were 30 students in Class $X$ MIPA 1 as an experimental class and 27 students in Class MIPA 2 as a control class, data collection was done by using test and questionnaire techniques. The results of the study, it is known that the tcount for motivation obtained 6.631 results $>$ ttable $=1.671$, with a significant level $\alpha=0.05$ and $d k$ 55. Data collected for the analysis of learning outcomes with a significant level $\alpha=0.05$ and $d k 55$, note the tcount $=11.23>$ table $=1.671$. There are significant differences in motivation scores and student learning outcomes before and after learning interventions are used using a scientific approach. In conclusion, the scientific approach in learning biology has a significant influence on the motivation and learning outcomes

Keywords: learning outcomes, motivation, scientific approach. 


\section{PENDAHULUAN}

Pada kurikulum 2013 Ilmu Pengetahuan Alam merupakan mata pelajaran yang memiliki proporsi yang cukup besar dalam struktur kurikulum. Salah satunya yaitu mata pelajaran biologi. Pembelajaran biologi idealnya harus mampu menghasilkan out put yang memiliki karakter, dikarenakan biologi sebagai produk terdiri dari konsep, fakta, teori, hukum yang berkaitan tentang mahluk hidup (Marjan et al, 2014).

Pembelajaran biologi pada dasarnya harus mampu membekali peserta didik cara mengetahui konsep, fakta secara mendalam, serta harus mampu memberikan kepuasan intelektual terutama dalam membangun kemampuan berpikir, karena kemampuan berpikir ini akan berimplikasi terhadap pengetahuan (kognitif), sikap (afektif), keterampilan (psikomotor). Ketiga komponen tersebut merupakan out put atau hasil yang harus diperoleh setelah belajar biologi (Razak et al, 2016).

Guru sebagai pengajar perlu mengatasi hal tersebut, dengan menerapkan strategi pembelajaran yang menarik bagi siswa agar siswa aktif dalam pembelajaran biologi. Penggunaan strategi yang tepat dalam kurikulum 2013 salah satunya melalui pendekatan saintifik. Pembelajaran dengan pendekatan saintifik adalah proses pembelajaran yang diracang sedemikian rupa agar peserta didik secara aktif mengkontruksi konsep, hukum atau prinsip melalui tahapantahapan mengamati (untuk mengidentifikasi atau menemukan masalah), merumuskan masalah, mengajukan atau merumuskan hipotesis, mengumpulkan data dengan berbagai teknik, menganalisis data, menarik kesimpulan dan mengkomunikasikan konsep, hukum atau prinsip yang ditemukan (Daryanto, 2014).

Hasil Penelitian Samitra et al (2018) model pembelajaran Guided Note Taking berpengaruh terhadap hasil belajar biologi siswa. Kemudian hasil penelitian Rozi et al (2018) aktivitas belajar biologi siswa lebih meningkat setelah diberikan perlakuan dengan menggunakan model Cooperative Script. Hasil penelitian Triyanti \& Nulhakim (2018) model pembelajaran student acilitator and explaining dapat meningkatkan hasil belajar biologi. Hasil penelitian Nesi \& Akobiarek (2018) terdapat pengaruh yang sangat signifikan antara metode pembelajaran dan minat atau pengaruh metode terhadap hasil belajar IPA. Hasil penelitian Sundari (2018) model pembelajaran discovery learning dapat meningkatkan hasil belajar dan aktivitas belajar siswa.

Adapun dalam penelitian ini meningkatkan motivasi dan hasil belajar siswa melalui pendekatan saintifik. Menurut Marjan (2014), pembelajaran pendekatan saintifik sangat cocok diajarkan pada mata pelajaran biologi sebagai proses pembelajaran yang menarik. Sehingga pembelajaran pendekatan saintifik mampu meningkatkan hasil belajar biologi disebabkan karena pendekatan saintifik 
ini memberikan keterlibatan langsung siswa dalam menggali dan menemukan konsep berdasarkan fakta yang mereka temukan.

\section{METODE PENELITIAN}

Penelitian ini menggunakan metode penelitian kuntitatif dengan jenis penelitian eksperimen murni menggunakan desain pre-test and post-test group design. Metode kuantitatif karena data penelitian berupa angka-angka dan analisis menggunakan statistik. Populasi penelitian adalah kelas X MIPA sebanyak 3 kelas berjumlah 88 siswa. Sampel penelitian terdiri dari dua kelas yaitu kelas X MIPA 1 dan X MIPA 2 yang diambil secara random sampling. Kelas X MIPA 1 sebanyak 30 sampel sebagai kelas eksperimen yang di beri perlakuan dengan menggunakan pendekatan saintifik dan kelas X MIPA 2 sebanyak 26 sampel sebagai kelas kontrol yang di beri perlakuan proses pembelajaran konvensional seperti yang diajarkan guru sebelumnya.

Teknik pengumpulan data menggunakan metode tes untuk memperoleh data hasil kognitif, metode angket untuk mengetahui hasil motivasi siswa. Uji hipotesis motivasi dan hasil belajar menggunakan uji t dan uji t' (semu). Uji statistik dilakukan pada taraf signifikan 5\%. Dalam penelitian ini persyaratan yang harus dipenuhi terlebih dahulu, sebelum melakukan uji hipotesis adalah data harus melalui uji normalitas dan uji homogenitas.

\section{HASIL PENELITIAN}

Data dalam penelitian ini meliputi data hasil belajar kognif dan hasil motivasi siswa. data diperoleh dari hasil tes dan angket pada siswa kelas X MIPA 1 yang berjumlah 30 siswa dan X MIPA 2 yang berjumlah 27 siswa. pada penelitian ini siswa kelas X MIPA 1 sebagai kelas eksperimen dan X MIPA 2 sebagai kelas kontrol. Berdasarkan penelitian yang dilakukan di SMA NEGERI 6 Model Lubuklinggau, diperoleh hasil sebagai berikut.

\section{Motivasi Siswa}

Tabel 1. Rekapitulasi Indikator Motivasi Awal dan Akhir

\begin{tabular}{ccccccc}
\hline Indikator & $\begin{array}{c}\text { Rata-Rata } \\
\text { Motivasi } \\
\text { Awal } \\
\text { Eksperimen }\end{array}$ & $\begin{array}{c}\text { Rata-Rata } \\
\text { Motivasi } \\
\text { Akhir } \\
\text { Eksperimen }\end{array}$ & Persentase & $\begin{array}{c}\text { Rata-Rata } \\
\text { Motivasi } \\
\text { Awal } \\
\text { Kontrol }\end{array}$ & $\begin{array}{c}\text { Rata-Rata } \\
\text { Motivasi } \\
\text { Akhir } \\
\text { Kontrol }\end{array}$ & Persentase \\
\hline $\begin{array}{c}\text { Tekun dalam } \\
\text { menghadapi tugas }\end{array}$ & 14,03 & 14,66 & $71 \%$ & 13,92 & 14,03 & $62 \%$ \\
\hline $\begin{array}{c}\text { Ulet dalam } \\
\text { menghadapi } \\
\text { kesulitan }\end{array}$ & 15,53 & 16,1 & $79 \%$ & 14,29 & 15,33 & $66 \%$ \\
\hline $\begin{array}{c}\text { Menunjukkan } \\
\text { minat }\end{array}$ & 14,4 & 15,93 & $75 \%$ & 13,51 & 14,70 & $63 \%$ \\
\hline $\begin{array}{c}\text { Senang bekerja } \\
\text { sendiri }\end{array}$ & 15,33 & 14,76 & $70 \%$ & 13,70 & 13,37 & $60 \%$ \\
\hline
\end{tabular}




\begin{tabular}{ccccccc}
\hline $\begin{array}{c}\text { Cepat bosan pada } \\
\text { tugas }\end{array}$ & 15,16 & 15,96 & $78 \%$ & 13,96 & 15,07 & $65 \%$ \\
\hline $\begin{array}{c}\text { Dapat } \\
\text { mempertahankan } \\
\text { pendapat }\end{array}$ & 13,8 & 15,3 & $72 \%$ & 13,77 & 14,22 & $63 \%$ \\
\hline $\begin{array}{c}\text { Senang mencari } \\
\text { dan memecahkan } \\
\text { soal-soal }\end{array}$ & 13 & 15,5 & $71 \%$ & 13,55 & 13,03 & $62 \%$ \\
\hline
\end{tabular}

Berdasarkan tabel 1 diatas, secara keseluruhan dapat disimpulkan bahwa kelas eskperimen dan kelas kontrol rata-rata indikator motivasi akhir lebih tinggi dibandingkan rata-rata indikator motivasi awal.

Tabel 2. Rekapitulasi Data Hasil Angket Motivasi Awal dan Akhir

\begin{tabular}{lccc}
\hline Data & Kelas & Rata-rata & Simpangan Baku \\
\hline \multirow{2}{*}{ Awal } & Eksperimen & 70,9 & 4,95 \\
\cline { 2 - 4 } & Kontrol & 69,1 & 6,42 \\
\hline \multirow{2}{*}{ Akhir } & Eksperimen & 77,30 & 7,20 \\
\cline { 2 - 4 } & Kontrol & 71,26 & 4,55 \\
\hline
\end{tabular}

Berdasarkan data pada tabel di atas, dapat dilihat bahwa nilai rata-rata angket motivasi awal kelas eksperimen sebesar 70,9 dan simpangan baku angket motivasi awal kelas eskperimen sebesar 4,95. Pada kelas kontrol nilai rata-rata angket motivasi awal sebesar 69,1 dan simpangan baku sebesar 6,42. Hal ini berarti angket motivasi awal rata-rata siswa kelas eksperimen lebih besar dari kelas kontrol. Sedangkan nilai rata-rata angket motivasi akhir kelas eksperimen sebesar 77,30 dan simpangan baku 7,20. Pada kelas kontrol nilai rata-rata angket motivasi akhir sebesar 71,26 dan simpangan baku 4,55. Jadi dapat disimpulkan nilai rata-rata angket motivasi akhir kelas eksperimen lebih besar dari nilai ratarata angket motivasi akhir kelas kontrol.

Uji hipotesis untuk hasil motivasi analisis uji-t untuk angket motivasi awal kelas eksperimen dan kelas kontrol memiliki kemauan motivasi yang sama karena $t_{\text {hitung }}=1,677<t_{\text {tabel }}=2,000$, sehingga Ho diterima dan Ha ditolak. Sedangkan hasil analisis uji $\mathrm{t}$ semu (t') untuk angket motivasi akhir kelas eksperimen dan kelas kontrol memiliki kemauan akhir yang tidak sama karena nilai $t_{\text {hitung }}=6,631>\mathrm{t}_{\text {tabel }}=1,671$, sehingga dapat disimpulkan bahwa terdapat perbedaan antara motivasi awal dan motivasi akhir yaitu Ho ditolak dan $\mathrm{Ha}$ diterima.

\section{Hasil Belajar Siswa}

Tabel 3. Rekapitulasi Data Hasil Pre-test dan Post-test

\begin{tabular}{cccc}
\hline Data & Kelas & Rata-rata & Simpangan Baku \\
\hline Pre - & Eksperimen & 35,57 & 8,24 \\
\cline { 2 - 4 } test & Kontrol & 28,70 & 7,48 \\
\hline Post- & Eksperimen & 74,80 & 9,34 \\
\hline
\end{tabular}




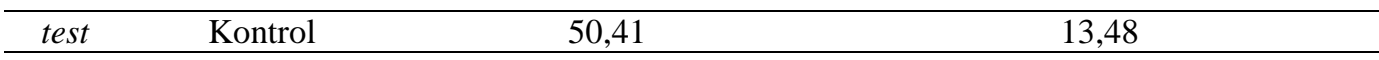

Berdasarkan data diatas dapat dilihat bahwa nilai rata-rata pre-test kelas eksperimen sebesar 35,57 dan simpangan baku pre-test kelas eskperimen sebesar 8,24. Pada kelas kontrol nilai rata-rata pre-test sebesar 28,70 dan simpangan baku sebesar 7,48. Hal ini berarti kemampuan rata-rata siswa kelas eksperimen lebih besar dari kelas kontrol. Sedangkan nilai rata-rata kelas eksperimen sebesar 74,80 dan simpangan baku 9,34. pada kelas kontrol nilai rata-rata post-test sebesar 50,41 dan simpangan baku 13,48. Jadi dapat disimpulkan nilai rata-rata kelas eksperimen lebih besar dari nilai rata-rata kelas kontrol.

Uji hipotesis untuk hasil belajar analisis uji-t untuk pre-test kelas eksperimen dan kelas kontrol memiliki kemampuan awal yang sama karena $t_{\text {hitung }}$ $=1,58<\mathrm{t}_{\text {tabel }}=2,000$, sehingga Ho diterima dan Ha ditolak. Sedangkan hasil analisis uji $\mathrm{t}$ semu ( $\left.\mathrm{t}^{\prime}\right)$ untuk post-test kelas eksperimen dan kelas kontrol memiliki kemampuan akhir yang tidak sama karena nilai $\mathrm{t}_{\text {hitung }}=11,23>\mathrm{t}_{\text {tabel }}=1,671$, sehingga dapat disimpulkan bahwa terdapat perbedaan antara hasil belajar eksperimen dan hasil belajar kontrol yaitu Ho ditolak dan Ha diterima.

\section{PEMBAHASAN}

Penelitian yang telah dilaksanakan dikelas X MIPA SMA Negeri 6 Model Lubuklinggau dapat dilihat dari perbandingan pre-test dan hasil post-test yang diberikan sebelum dan setelah proses pembelajaran yang dilakukan pada kedua sampel. Dan mengukur motivasi belajar siswa dengan menggunakan angket motivasi yang dilakukan pada awal sebelum proses pembelajaran dan akhir setelah proses pembelajaran.

\section{Motivasi Siswa}

Pada pertemuan pertama dilakukan pemberian angket motivasi kepada siswa untuk mengukur motivasi siswa dalam proses pembelajaran. Hal ini sesuai yang dijelaskan Sardiman (2011), yang menyatakan bahwa motivasi juga dikatakan serangkaian usaha untuk menyediakan kondisi-kondisi tertentu. Motivasi juga dapat dirangsang oleh faktor dari luar tetapi motivasi itu adalah tumbuh didalam diri seseorang.

Pemberian angket motivasi awal pada kelas kontrol diperoleh rata-rata 69,14 kategori cukup, dan memiliki presentase 41\% cukup dan 59\% baik. Sedangkan angket awal pada kelas eksperimen diperoleh rata-rata 70,76 kategori baik, dan memiliki presentase $37 \%$ cukup dan $63 \%$ baik. Sehingga memperoleh data analisa tes angket motivasi awal melalui uji-t bahwa $\mathrm{t}_{\text {hitung }} 1,677<\mathrm{t}_{\text {tabel }}=$ 2,000, sehingga Ho diterima dan Ha ditolak. Hal ini berarti kedua kelas memiliki motivasi yang sama.

Pada pertemuan kedua siswa kelas eksperimen dan kelas kontrol masih kurang motivasi dalam melaksanakan proses belajar mengajar, hal ini disebabkan 
siswa masih ingin bermain-main sehingga motivasi untuk belajarnya masih kurang. Hal ini sesuai dengan Dimyati \& Mudjiono (2009), yang menyatakan bahwa dorongan atau dukungan adalah kekuatan mental inti dari adanya motivasi dari diri siswa. sehingga siswa dapat memperoleh hasil belajar yang tinggi.

Pada pertemuan ketiga tanggal siswa kelas kontrol dan eksperimen sudah adanya kemajuan motivasi dalam proses pembelajaran dan siswa lebih antusias dalam melaksanakan pembelajaran di kelas dengan menggunakan pendekatan saintifik. Hal ini sesuai yang dijelaskan Hamalik (2012), yang menyatakan bahwa motivasi dimulai dari adanya perubahan energi dalam diri dan pribadi yang bermotivasi mengadakan respon yang tertuju kearah suatu tujuan.

Pada pertemuan keempat dilakukan pemberian angket motivasi akhir pada siswa kelas kontrol diperoleh rata-rata 71,18 kategori baik dan memiliki presentase $30 \%$ cukup, $66 \%$ baik, dan $4 \%$ sangat baik. Sedangkan pada kelas eksperimen diperoleh rata-rata 77,30 kategori baik dan memiliki presentase 3\% cukup, $50 \%$ baik dan $47 \%$ sangat baik. Sehingga dapat disimpulkan bahwa dari pemberian motivasi awal sampai pemberian motivasi akhir terdapat perubahan motivasi belajar siswa menjadi lebih baik dari sebelumnya karena sudah terlihat atusias siswa dalam proses pembelajaran. Hal ini sesuai dengan Bilatu (2016), bahwa dengan adanya motivasi dan tindakan yang berkelanjutan dari guru dapat memberikan pengaruh yang berarti bagi hasil belajar siswa.

Pada saat pemberian angket motivasi akhir pada akhir pembelajaran pada pertemuan keempat nilai rata-rata angket motivasi akhir kelas eksperimen lebih besar dari hasil angket motivasi akhir kelas kontrol. Sehingga hasil yang diperoleh $\mathrm{t}_{\text {hitung }}=6,631>\mathrm{t}_{\text {tabel }}=1$,671. Jadi disimpulkan bahwa terdapat pengaruh pendekatan saintifik terhadap motivasi belajar biologi siswa. Motivasi dapat dilihat proses pembelajaran dikelas, semakin lama siswa semakin termotivasi dalam mengikuti proses pembelajaran. Didukung oleh Hamalik (2012), yang menyatakan bahwa tingkah laku manusia didorong oleh motif-motif tertentu dan perbuatan belajar akan berhasil apabila didasarkan pada motivasi yang ada pada siswa. Sesuai dengan peneliti Talango (2017), yang menyatakan bahwa pendekatan saintifik sangat cocok terutama untuk membangkitkan semangat atau motivasi siswa dalam mengikuti proses pembelajaran.

Pada indikator motivasi awal dan akhir kelas eksperimen didapatkan indikator pertama rata-rata motivasi awal 14,03 rata-rata motivasi akhir 14,66 dengan presentase $71 \%$, indikator kedua rata-rata motivasi awal 15,53 rata-rata motivasi akhir 16,1 dengan presentase $79 \%$, indikator ketiga rata-rata motivasi awal 14,4 rata-rata motivasi akhir 15,93 dengan presentase $75 \%$, indikator keempat rata-rata motivasi awal 15,33 rata-rata motivasi akhir 14,76 dengan presentase $70 \%$, indikator kelima rata-rata motivasi awal 15,16 rata-rata motivasi akhir 15,96 dengan presentase $78 \%$, inidikator keenam rata-rata motivasi awal 
13,8 rata-rata motivasi akhir 15,3 dengan presentase $72 \%$ dan indikator ketujuh rata-rata motivasi awal 13 rata-rata motivasi akhir 15,5 dengan presentase $71 \%$.

Sedangkan indikator motivasi awal dan akhir kelas kontrol didapatkan indikator pertama rata-rata motivasi awal 13,92 rata-rata motivasi akhir 14,03 dengan presentase $62 \%$, indikator kedua rata-rata motivasi awal 14,29 rata-rata motivasi akhir 15,33 dengan presentase $66 \%$, indikator ketiga rata-rata motivasi awal 13,51 rata-rata motivasi akhir 14,70 dengan presentase 63\%, indikator keempat rata-rata motivasi awal 13,70 rata-rata motivasi akhir 13,37 dengan presentase $60 \%$, indikator kelima rata-rata motivasi awal 13,96 rata-rata motivasi akhir 15,07 dengan presentase $65 \%$, inidikator keenam rata-rata motivasi awal 13,77 rata-rata motivasi akhir 14,22 dengan presentase $63 \%$ dan indikator ketujuh rata-rata motivasi awal 13,55 rata-rata motivasi akhir 13,03 dengan presentase $71 \%$.

Dapat disimpulkan bahwa pada kelas eksperimen indikator 1, 2, 3, 5, 6, 7 mengalami peningkatan dari pemberian angket motivasi awal sampai pemberian angket motivasi akhir sedangkan pada kelas kontrol dapat disimpulkan bahwa indikator 1, 2, 3, 5, 6, mengalami peningkatan dari pemberian angket motivasi awal sampai pemberian angket motivasi akhir dan presentase paling tinggi kedua kelas yaitu indikator kedua.

Pada indikator pertama tekun dalam menghadapi tugas di peroleh $71 \%$ untuk kelas eksperimen dan 62\% kelas kontrol, di karenakan siswa pada kelas eksperimen dan kontrol sangat semangat untuk menyelesaikan tugas. Seperti dalam proses pembelajaran dikelas siswa sangat semangat saat mengerjakan LKS yang di bagikan oleh peneliti untuk dikerjakan disekolah. Menurut Sardiman (2011), siswa dapat bekerja terus menerus dalam waktu lama, bersungguhsungguh dalam menyelesaikan suatu pekerjaan dan tidak pernah berhenti sebelum pekerjaan selesai.

Pada indikator kedua ulet dalam menghadapi kesulitan di peroleh $79 \%$ kelas eksperimen dan 66\% kelas kontrol, indikator kedua ini dikategorikan tinggi dari indikator lainnya. Karena siswa yang mempunyai tingkat motivasi belajar yang tinggi tidak mudah putus asa dalam menghadapi berbagai kesulitan dalam belajar. Menurut Solina (2013), ulet berarti tidak mudah putus asa yang disertai dengan kemauan keras dan usaha dalam mencapai tujuan. Ulet dalam menghadapi kesulitan dapat dilihat dari sikap terhadap kesulitan dan usaha mengatasi kesulitan.

Pada indikator ketiga menunjukkan minat di peroleh $75 \%$ kelas eksperimen dan 63\% kelas kontrol. Siswa menjadi lebih tertarik dalam proses pembelajaran di kelas karena menggunakan pendekatan saintifik yang memiliki langkah-langkah dalam proses pembelajaran. Menurut Sardiman (2011), karena 
menunjukkan kesukaan pada suatu hal misal masalah-masalah dalam pembelajaran seperti disoal-soal.

Pada indikator keempat senang bekerja mandiri di peroleh $70 \%$ di kelas eksperimen dan $60 \%$ di kelas kontrol. Di indikator keempat ini siswa lebih senang untuk bekerja sendiri jadi dapat menyelesaikan permasalahan yang ada di setiap soal. Menurut Hamalik (2012), siswa menjadi tidak tergantung pada orang lain.

Pada indikator kelima cepat bosan pada tugas-tugas di peroleh $78 \%$ kelas eksperimen dan 65\% kelas kontrol. Indikator kelima ini juga merupakan presentase yang tinggi karena siswa cepat bosan jika setiap selesai proses pembelajaran diberikan tugas rutin untk dikerjakan dirumah. Pada indikator keenam dapat mempertahankan pendapat di peroleh $72 \%$ kelas eksperimen dan $63 \%$ kelas kontrol, siswa belajar untuk dapat konsisten dengan apa yang menjadi pendapatnya. Menurut Solina (2013), kalau sudah yakin dengan sesuatu siswa menjadi pendirian yang tetap.

Pada indikator ketujuh senang mencari dan memecahkan soal di peroleh $71 \%$ kelas eksprimen dan $62 \%$ kelas kontrol, presentase ini juga tinggi karena siswa dalam proses pmbelajaran sangat senang dalam memecahkan masalah soalsoal yang ada di buku dan di sumber lainnya. Menurut Sardiman, (2011), seseorang yang tinggi tingkat motivasinya akan giat berusaha, tampak gigih tidak mau menyerah, giat membaca buku-buku untuk menambah pengetahuannya untuk memecahkan masalahnya.

\section{Hasil Belajar Siswa}

Pada saat pertemuan pertama guru mengabsen siswa dan memperkenalkan diri serta menjelaskan maksud dan tujuan guru melakukan penelitian setelah itu guru memberikan angket motivasi terlebih dahulu kepada siswa kemudian diiringi dengan memberikan pre-test. Pre-test merupakan tes pertama untuk mengetahui kemampuan siswa sebelum menerima materi pembelajaran. Pada saat pre-test masih terdapat kesalahan sehingga nilai siswa masih rendah. Dan analisa data tes awal melalui uji-t dengan taraf kepercayaan $\alpha=0,05 \%$ serta $\mathrm{dk}=55$ diperoleh bahwa $t_{\text {hitung }}=1,58<\mathrm{t}_{\text {tabel }}=2,000$, sehingga Ho diterima dan Ha ditolak. Hal ini berawal dari keadaan yang sama, sehingga nilai siswa masih rendah. Menurut Razak (2016), yang menyatakan bahwa nilai seluruh siswa masih rendah dikarenakan belum menerima materi kompetensi yang diujikan.

Setelah mengerjakan pre-test lanjut kemateri pertemuan pertama yaitu mengidentifikasi komponen penyusun ekosistem dengan metode eksperimen siswa disuruh untuk mengamati faktor biotik dan abiotik yang ada dilingkungan sekolah secara berkelompok. Hasil dari mengamati dilapangan di presentasikan atau dibahas di depan kelas. Pada pertemuan pertama ini siswa masih belum memahami langkah-langkah pendekatan saintifik. 
Pada pertemuan kedua proses belajar pembelajaran menggunakan pendekatan saintifik dengan langkah-langkah pada pendekatan tersebut. Materi yang dibahas pada pertemuan kedua yaitu siswa dapat membedakan suksesi primer dan suksesi sekunder. Pada pertemuan kedua ini siswa masih belum terlalu mengikuti langkah-langkah dalam pendekatan saintifik, karena masih ada siswa yang belum sepenuhnya memahami langkah-langkah dalam pendekatan saintifik. Sehingga proses belajar mengajar belum berjalan dengan aktif. Sesuai yang dijelaskan oleh Daryanto (2014), yang menyatakan bahwa pendekatan saintifik itu dirancang agar siswa dapat aktif mengkontruksi konsep dan memahami tahaptahapan dalam proses pembelajaran. Jadi ketika proses pembelajaran pendekatan saintifik masih baru dilakukan siswa masih mengalami kesulitan dalam proses pembelajaran.

Pada pertemuan ketiga dengan materi mekanisme aliran energi suatu ekosistem, siswa sudah mulai memahami dan mengikuti langkah-langkah dalam pendekatan saintifik dengan baik dan aktif. Hal ini dijelaskan oleh Marjan (2014), yang menyatakan bahwa pendekatan saintifik ini menekankan pada keaktifan siswa dalam belajar. Sehingga siswa mulai aktif dam pembelajaran dan sudah memahami langkah-langkah dalam pendekatan saintifik.

Pada pertemuan keempat dengan materi yang berbeda yaitu materi peran mikroorganisme/organisme dalam daur biogeokimia. Pada pertemuan keempat ini siswa sudah lebih memahami langkah-langkah pendekatan saintifik sehingga proses belajar mengajar jadi lebih baik dari sebelumnya. Sehingga siswa dengan mudah mengikuti langkah-langkah dalam proses pembelajaran. Seperti yang dijelaskan oleh Sani (2015), yang menyatakan bahwa pendekatan saintifik ini memiliki langkah-langkah yaitu mengamati, menanya, mengumpulkan informasi, mengasosiasi, menarik kesimpulan, dan mengkomunikasikan. Hal ini yang membuat siswa lebih aktif dalam mengikuti pembelajaran dikelas.

Setelah diberi pembelajaran yang berbeda, pada kelas eksperimen menggunakan pendekatan saintifik sedangkan kelas kontrol menggunakan pendekatan konvensional. Kemudian kedua kelas sampel diberi post-test sehingga terjadi peningkatan hasil belajar. Kelas eksperimen nilai rata-rata sebesar 74,80 dibandingkan nilai tes awal sebesar 35,57, maka terdapat peningkatan dari pre-test dan post-test kelas eksperimen. Pada kelas kontrol nilai rata-rata sebesar 50,41 dibandingkan nlai tes awal sebesar 28,70, maka terdapat peningkatan dari pre-test dan post-test kelas kontrol.

Berdasarkan analisis uji-t semu ( $\left.\mathrm{t}^{\prime}\right)$ dengan taraf kepercayaan $\alpha=0,05 \%$ dan $\mathrm{dk}=55$ sehinggat didapat $\mathrm{t}_{\text {hitung }}=11,23>\mathrm{t}_{\text {tabel }}=1,671$. Hal ini menunjukkan nilai rata-rata kelas ekperimen lebih besar dari nilai rata-rata kelas kontrol. Dengan demikian, hasil belajar siswa yang mengikuti pembelajaran dengan menggunakan pendekatan saintifik lebih besar dari pada hasil belajar siswa yang 
mengikuti pembelajaran dengan menggunakan pendekatan konvensional. Sehingga ada pengaruh pendekatan saintifik terhadap hasil belajar siswa. Sesuai dengan penelitian yang dilakukan oleh Marjan (2014), yang menyatakan bahwa pembelajaran pendekatan saintifik ini mampu meningkatkan hasil belajar siswa.

Menurut Sani (2015), pendekatan saintifik umumnya melibatkan kegiatan pengamatan atau percobaan yang dibutuhkan untuk mengumpulkan data. Oleh karena itu percobaan dapat diganti dengan kegiatan memperoleh informasi dari berbagai sumber. Menurut Wartini (2014), proses pembelajaran menggunakan pendekatan saintifik siswa jadi lebih banyak terlibat langsung untuk menggali informasi ataupun melakukan pengamatan dengan kelompok masing-masing. Pendekatan saintifik menekankan pada proses pembelajaran yang lebih banyak melibatkan siswa untuk mengalami sendiri apa yang dipelajari. Berdasarkan beberapa pernyataan bahwa pendekatan saintifik merupakan kegiatan yang melibatakan seluruh kegiatan siswa sehingga mendapatkan hasil belajar yang maksimal.

Berdasarkan penelitian relevan Bilatu, (2016) menunjukkan bahwa dengan menggunakan pembelajaran pendekatan saintifik dapat meningkatkan motivasi dan meningkatkan hasil belajar siswa. Dengan peningkatan tersebut maka pendekatan saintifik ini dapat digunakan dalam proses pembelajaran sehingga mendorong siswa dalam mencapai hasil belajar yang lebih baik dari sebelumnya. Berdasarkan peneliti Sumayasa (2015), pendekatan saintifik mampu memenuhi apa yang dibutuhkan siswa selama pendidik selalu berupaya untuk merancang pembelajaran yang bermakna agar dapat meningkatkan motivasi belajar siswa dan meningkatkan hasil belajar siswa.

\section{SIMPULAN}

Pendekatan saintifik dalam pembelajaran biologi memiliki pengaruh yang signifikan terhadap motivasi dan hasil belajar siswa

\section{DAFTAR PUSTAKA}

Bilatu, N., Rede, A., \& Pursitasari, D. (2016). Implementasi Model Pembelajaran Investigasi Kelompok Berbasis Pendekatan Saintifik Untuk Meningkatkan Motivasi dan Hasil Belajar Siswa pada Mata Pelajaran IPA di Kelas IV SD Inpres 2 Tondo. Jurnal Mitra Sains, 4 (3); 67-77.

Daryanto. (2014). Pendekatan Pembelajaran Saintifik Kurikulum 2013. Yogyakarta: Gaya Media

Dimyati \& Mudjiono. (2009). Belajar dan Pembelajaran. Jakarta: Rineka Cipta. Hamalik, O. (2012). Proses Belajar Mengajar. Jakarta: Bumi Aksara.

Marjan, J., Arnyana, P., \& Setiawan, N. (2014). Pengaruh Pembelajaran PendekatanSantifik Terhadap Hasil Belajar Biologi dan Keterampilan Proses Sains Siswa MA Mu'allimat NW Pancor Selong Kabupaten 
Lombok Timur Nusa Tenggara Barat. Jurnal Program Pascasarjana Universitas Pendidikan Ganesha, 4(1); 1-12.

Nesi, M., \& Akobiarek, M. (2018). Pengaruh Minat dan Penggunaan Metode terhadap Hasil Belajar IPA Biologi Siswa Kelas VII SMP Negeri 2 Jayapura. BIOEDUSAINS: Jurnal Pendidikan Biologi Dan Sains, 1(1), 8094. https://doi.org/https://doi.org/10.31539/bioedusains.v1i1.257

Razak, M., Hala, Y., \& Taiyeb, M, A. (2016). Efektifitas Pendekatan Saintifik Terhadap Keterampilan Proses Sains dan Hasil Belajar Kognitif Biologi Peserta Didik Kelas XII IPA SMA Negeri 4 Watampoe, 5(1); 58-73.

Rozi, Z., Harmoko, H., \& Teresa, F. (2018). Pengaruh Model Cooperative Script terhadap Aktivitas dan Hasil Belajar Biologi Siswa Kelas VIII SMP Negeri 7 Lubuklinggau. BIOEDUSAINS: Jurnal Pendidikan Biologi Dan Sains, $\quad 1(1)$ : 23-33. https://doi.org/https://doi.org/10.31539/bioedusains.v1i1.256

Samitra, D., Krisnawati, Y., \& Malasari, N. (2018). Pengaruh Model Guided Note Taking terhadap Hasil Belajar Biologi Siswa Kelas XI SMA Negeri 6 Kota Lubuklinggau. BIOEDUSAINS: Jurnal Pendidikan Biologi Dan Sains, 1(1); 1-10. https://doi.org/https://doi.org/10.31539/bioedusains.v1i1.237

Sani, A., R. (2015). Pembelajaran Saintifik untuk Implementasi Kurikulum 2013. Jakarta: Bumi Aksara.

Sardiman. (2011). Interaksi dan Motivasi Belajar Mengajar. Jakarta: Raja Grafindo Persada.

Solina, W., Erlamsyah., \& Syahniar. (2013). Hubungan Antara Perlakuan Orang Tua Dengan Motivasi Belajar Ssiswa Di Sekolah. Jurnal Ilmiah Konseling, 5(1); 289-294.

Sumayasa, N, I., Marhaeni, N, I, A., \& Dantes, N. (2015). Pengaruh Implementasi Pendekatan Saintifik Trehadap Motivasi Belajar dan Hasil Belajar Bahasa Indonesia Pada Siswa Kelas VI di Sekolah Dasar Segugus VI Kecamatan Abang Karangasem. Jurnal Pascasarjana Universitas Pendidikan Ganesha, 5 (1); 1-11.

Sundari, S. (2018). Peningkatan Hasil Belajar Biologi dengan Model Discovery Learning. BIOEDUSAINS: Jurnal Pendidikan Biologi Dan Sains, 1(2); 143-154. https://doi.org/https://doi.org/10.31539/bioedusains.v1i2.449

Talango, S. (2017). Pengaruh Pendekatan Saintifik Terhadap Hasil Belajar Matematika Ditinjau Dari Motivasi Belajar. Jurnal Riset dan Pengembangan Ilmu Pengetahuan, 2(1); 172-176.

Triyanti, M., \& Nulhakim, U. (2018). Upaya Peningkatan Hasil Belajar Biologi Siswa Kelas X Menggunakan Model Pembelajaran Student Acilitator And Explaining. BIOEDUSAINS: Jurnal Pendidikan Biologi Dan Sains, 1(1), 43-51. https://doi.org/https://doi.org/10.31539/bioedusains.v1i1.246

Wartini, M, A, I., Lasmawan, W, I., \& Marhaeni, N, I, A. (2014). Pengaruh Implementasi Pendekatan Saintifik Terhadap Sikap Sosial dan Hasil Belajar Pkn di Kelas VI SD jembatan Budaya Kuta. Jurnal Program Pascasarjana Universitas Pendidikan Ganesha, 4(1); 1-11. 